\title{
Small Intestinal Wall Tissue
}

National Cancer Institute

\section{Source}

National Cancer Institute. Small Intestinal Wall Tissue. NCI Thesaurus. Code C33573.

The tissue of the small intestine. It comprises four layers - mucosa with simple columnar epithelium, submucosa, smooth muscle with inner circular and outer long itudinal layers, and serosa. 